\title{
Mahzar-namas in the Mughal and British Empires: The Uses of an Indo-Islamic Legal Form
}

\author{
NANDINI CHATTERJEE
}

\author{
University of Exeter
}

\section{INTR ODUCTION}

In the year 1684, the Mughal emperor Aurangzeb 'Alamgir' ${ }^{1}$ was reigning in Shahjahanabad (Delhi) but engaged in what turned out to be an endless war with the rebel Marathas in western India. ${ }^{2}$ That same year, Purshottam Das, a petty landlord in central India (province Malwa, district Dhar) recorded his family's history and rights in a type of document called mahzar-nama. The headmanship (chaudhurai) and the police station (chabutra-i kotwali) of Dhar had been in the family, he said, since the time of his grandfather, Jayant Das. Jayant Das's son, Mohan Das was a valiant man who had protected the district and the crucial highway that passed through it from the depredations of a neighboring landlord. As a reward, Mohan Das gained the office of district chaudhuri for his lifetime and obtained confirmatory documents (sanads) to

Acknowledgments: The basic research for this article was enabled by a grant from the International Placement Scheme of the AHRC, UK. I warmly thank Christoph Werner and Paolo Sartori for their generous advice, Chander Shekhar for teaching me to read the Persian of Indian legal documents, and the anonymous $\mathrm{CSSH}$ reviewers for their meticulous readings of an earlier version.

${ }^{1}$ Regarding transliteration, for Persian and Arabic words, I have used a system based on a modification of F. J. Steingass, A Comprehensive Persian-English Dictionary (London: Routledge \& Kegan Paul, 1892). I have avoided the use of diacritics except for the 'ain. I have therefore not indicated the length of vowels, nor used the hamza to indicate consecutive distinctly pronounced vowels. In case of Arabic words commonly in use in Persian and Hindi/Urdu (such as qazi), my transliteration reflects the South Asian pronunciation pattern. I have indicated the possessive $i z a f a$ with $-i$ and with $-y i$ where it follows a vowel ending. With certain very well-known names, such as Abul Fazl, I have side-stepped accurate transcription in favor of the most widely used orthography in English. When quoting from others' works or reproducing book titles, I have reproduced the transliteration system in the quotes. I use the English plural signifier $s$ to pluralize Arabic, Persian, and Hindi/Urdu words.

2 The Mughals (a Persian mis-appellation of "Mongol") were a Turko-Mongol dynasty of Central Asian origin that established its rule in north India in 1526. Mughal power declined rapidly after the sixth emperor Aurangzeb's death in 1707, although officially they remained sovereigns of India until 1857. For an introduction, see J. F. Richards, The Mughal Empire (Cambridge: Cambridge University Press, 1993). For a history of the Marathas, see Stewart Gordon, The Marathas (Cambridge: Cambridge University Press, 1993). 
this effect. When Mohan Das died, the duties and perquisites of headmanship and the police station were granted to his younger brother Chandar Bhan, who unfortunately suffered a burglary in which the documents were lost. Nevertheless, in his lifetime, Chandar Bhan managed to have his nephew Purshottam Das named as his successor. After coming into his inheritance, Purshottam Das astutely managed to secure a princely order (nishan) confirming his office and emoluments, no doubt to replace the stolen documents. All had been well for nine years since that ratification, but in 1684, Purshottam Das was faced with challenges to his position from two men called Kanwal Das and Tilok Chand. Thus he appealed to all those who knew that these upstarts had no ancestral claim to the two offices to render their testimony (gawahi) in writing. ${ }^{3}$

Clearly, what had motivated Purshottam Das to hire Persian-writing scribes ${ }^{4}$ to record his family's history and entitlements and seek collective supporting endorsements was the presence of rival claimants to his offices and sources of income. This reveals him to have been a local grandee co-opted into the revenue and administrative machinery of the Mughal state, but constantly battling within local power dynamics to retain his official position. The mahzar-nama through which he asserted his claims is one among approximately a hundred pertaining to this family from Malwa. They range in date from the early seventeenth to the mid-eighteenth centuries, and in turn form part of several such sets of Persian-language "family papers" acquired by the National Archives of India and preserved there as part of the several-thousands-strong "Acquired Documents" series. ${ }^{5}$ Prolific and neglected documents of this kind allow us to expand upon the kind of local history of the Indian sub-continent's largest and most centralized precolonial state, which has only begun to be written. ${ }^{6} \mathrm{I}$ am currently engaged in such a project in another context. This article, however, invites readers to reflect upon the popular mahzar-nama documentary form in which Purshottam Das articulated

\footnotetext{
${ }^{3}$ Persian document no. 2703/62, National Archives of India, Delhi.

${ }^{4}$ Given the protagonist's social background, he probably could not write Persian himself. In other documents pertaining to the family, he signed his name in the margin in the Nagri character.

${ }^{5}$ While not described as such, a close reading of the catalogue descriptions of the five thousand to six thousand documents in this collection reveals that a large proportion must be from the collections of specific families. The National Archives of India provides no information about their process of acquiring or verifying these documents. But other subsets from the Acquired Documents series, such as the "Cambay documents," have been used with confidence by other scholars, for example Farhat Hasan, State and Locality in Mughal India: Power Relations in Western India, 1572-1730 (Cambridge: Cambridge University Press, 2004). I have also been able to trace a complementary set of documents pertaining to this family in the Dar al-Athar al-Islamiyyah, Kuwait. It contains mainly "higher-status" documents such as parwanas, which bear seals of officials and notes on the reverse, which correspond to Mughal chancellery procedure.

${ }^{6}$ Hasan, State and Locality. Jos Gommans has made very similar points regarding patterns of Mughal military recruitment, in Mughal Warfare: Indian Frontiers and the Highroads to Empire, 1500-1700 (London: Routledge, 2002).
} 
his family's history and his own claims. This presents an opportunity to explore key aspects of the legal culture of precolonial, mainly Mughal India and trace their evolution across the temporal and political divide of Mughal decline and the rise of the colonialism in South Asia.

The Arabic word mahzar has a range of meanings related to presence, and can indicate that which was present, made present, or represented. Mahzars (Arabic pl. mahazir) were a known documentary form in Islamic law, recommended by jurists (fuqaha) for the use of qazis (Islamic judges) to record their court proceedings, including evidence presented and judgment given. ${ }^{7}$ While Indian Islamic jurists reproduced and elaborated on these recommendations, extant Indian documents such as Purshottam Das's mahzar-nama point to other lives of this documentary form. Beginning with the "mis-appellation," which involved the addition of the Persian suffix "-nama," Indian mahzarnamas were distinctive for being narratives of entitlements, injuries, and related claims; articulated in the first person; penned by expert scribes who were generally not Muslims; endorsed in writing by members of the local community and/or the professional or social contacts of those writing the document (in common with other Islamic legal deeds) $;^{9}$ and for their production and uses being frequently extended to contexts beyond the qazi's courtroom. As such, mahzar-namas allow us to explore a mode of recording entitlements that has much to teach us about sociality, record-keeping, and consciousness of rights and history in precolonial South Asia. Because of the genre's longevity, we can also use it to trace the evolution of those aspects of legal culture

7 The Function of Documents in Islamic Law: The Chapters on Sales from Tahāwī's Kitāb al-shurūt al-kabīr, Jeanette Wakin, ed. and trans. (Albany: State University of New York Press, 1972), 9-29.

${ }^{8}$ The word is a typical Indo-Persian modification, involving a redundant suffix. The Persian suffix "nama" otherwise denotes a wide variety of written prose forms, including history, biography, legal documents, and letters. Moreover, the addition of this redundant suffix is unsystematic: while Purshottam Das's document self-describes itself as naql-i mahzar, similar documents from the same period and the neighboring province of Khandesh are self-described as mahzar-nama. For an example of the latter, see M. Ziauddin Ahmad, ed., Mughal Archives: A Descriptive Catalogue of the Documents Pertaining to the Reign of Shah Jahan (1652-1658), vol. I (Hyderabad: A. P. State Archives 1977), 325-27. Also, several (but again, not all) of the formularies on which these documents were based call the form of such documents mahzar-nama. Thus far, I have been unable to discover a perfectly consistent pattern, but it does appear that declarative documents of the southern and western Indian type (see below) were called mahzars, whereas evidentiary instruments of the kind that Purshottam Das used were most often called mahzar-namas. I have retained "mahzar-nama" to label the legal documentary form this article is concerned with, given its evident association with Indo-Persian chancellery culture, and its grouping in formularies with legal deeds such as bai'-nama (sale deeds), rahn-nama (pawn/mortgage deeds), and nikahnama (marriage contracts).

9 Witness clauses were a common feature in Islamic legal deeds, which recorded interpersonal property transactions such as sales and pawning. See Geoffrey Khan, Arabic Legal and Administrative Documents in the Cambridge Genizah Collections (Cambridge: Cambridge University Press, 1993). There are several such Persian-language legal deeds among the documents of Purshottam Das's family. 
across the colonial divide. Furthermore, because of the genre's recognizably Islamic as well as Persianate provenances, and its clear regionalization within South Asia's unique demographic and political context in which Islamic states ruled for centuries over non-Islamic populations, we can use it to speak to the vibrant and vast literature on Islamic law. This is important because, although this literature has by now put to rest older Orientalist notions of a fossilized legal system dominated by jurists incapable of responding to their social context, ${ }^{10}$ it has curiously neglected the context of South Asia. ${ }^{11}$

In what follows I also build upon Sumit Guha's valuable observations regarding the salient but contested place of the past in precolonial South Asian conceptions of law and rights. Guha made these in connection with a distinctive Marathi-language genre called bakhar, which began life as legal testimony and evolved into a genre of historical narrative. ${ }^{12}$ The mahzar-nama had a function very similar to that which Guha described for the bakhar - providing a legally cognizable account of past facts. Indeed, a distinctive form of the mahzar was deployed so often in the Marathi context that some scholars have clearly erred in thinking that specifically legal mahzar-namas were found only in southern

${ }^{10}$ Within the vast literature on Islamic law, some classics that have inspired this work are: Wael Hallaq, "Was the Gate of Ijtihad Closed?" International Journal of Middle East Studies 16, 1 (1984): 3-41; "From Fatwas to Furu': Growth and Change in Islamic Substantive Law," Islamic Law and Society 1 (Feb. 1994): 17-56; and Shari 'a: Theory, Practice, Transformations (Cambridge: Cambridge University Press, 2009); Brinkley Messick, The Calligraphic State: Textual Domination and History in a Muslim Society (Berkeley: University of California Press, 1993); and Judith E. Tucker, In the House of the Law: Gender and Islamic Law in Ottoman Syria and Palestine (Berkeley: University of California Press, 1998).

11 In general, scholarly interest in Islamic law in South Asia has been limited to accounts of its experience under colonial rule. Most scholars agree that colonialism rendered shari ' $a$ a fossilized and caricatured version of its former self. Scott A. Kugle, "Framed, Blamed and Renamed: The Recasting of Islamic Jurisprudence in Colonial South Asia," Modern Asian Studies 35, 2 (2001): 257-313; Gregory Kozlowski, Muslim Endowments and Society in British India (Cambridge: Cambridge University Press, 2008); Michael Anderson, "Islamic Law and the Colonial Encounter in British India," in David Arnold and Peter Robb, eds., Institutions and Ideologies: A South Asia Reader (Richmond: Routledge Curzon, 1993), 165-85. Even Wael Hallaq has little to add about Islamic law in South Asia beyond the narrative of colonial distortion; Shari ' $a$, 371-95. In contrast, scholars have underscored the intellectual richness and effective activism that scholars of Islamic law, both traditional and modern, remained capable of well into the twentieth century. Alan Günther, "Syed Mahmud and the Transformation of Muslim Law in British India," PhD thesis, McGill University, 2006; Rohit De, "Mumtaz Bibi’s Broken Heart: The Many Lives of the Dissolution of Muslim Marriages Act," Indian Economic and Social History Review 46, 1 (2009): 10530; Barbara Metcalf, Deoband: Islamic Revival in British India, 1860-1900 (Princeton: Princeton University Press, 1982); Muhammad Qasim Zaman, The Ulama in Contemporary Islam: Custodians of Change (Princeton: Princeton University Press, 2002). South Asian historiography on precolonial Islamic law remains curiously reticent. Scholars have instead focused on alternative codes of righteousness that scholars deem to have rendered shari 'a an "ambiguous" entity in India. Katherine Ewing, ed., Sharī' $a$ and Ambiguity in South Asian Islam (Berkeley: University of California Press, 1988).

12 Sumit Guha, "Speaking Historically: The Changing Voices of Historical Narration in Western India, 1400-1900," American Historical Review 109, 4 (2004): 1084-103. 
and south-western India. ${ }^{13}$ Although the mahzar-nama did not acquire its own literary avatar, as the bakhar did, its generic connection with the range of Persian-language compositions designated nama exposes an Indo-Persianate world peopled by professionals whose careers and achievements ranged from accountancy, to legal drafting, to history-writing: the world of South Asian scribes.

A relatively new interest in the social and cultural history of scribes and record-keeping, especially in South Asia, ${ }^{14}$ has since 2000 drawn historians to paying closer attention to the millions of documents that such men wrote. They documented transactions, recorded extractions, and produced a highly stylized version of "truth" that was coded in professionally shared formulae. Historians studying other colonial contexts have drawn attention to the consequences of the notary's "alchemic" products, in which unique events or claims were encoded in regularized textual expressions. They represented what was not necessarily true, but judiciable and legible to law (or the state), ${ }^{15}$ thereby generating endless possibilities of forgery, fraud, and oppression, and consequently a negative social image for themselves. ${ }^{16}$ Other scholars, especially early modernists, have examined the documents themselves as "historical artifacts $[$ sic]" bearing traces of "competing truths," the careful recovery of which can illuminate social conflicts and clashing mentalités, and rescue the premodern world from a reputation of harmonious homogeneity. ${ }^{17}$ Reflecting on the linguistic turn, Paolo Sartori has warned against abandoning the search for social facts in the obsession with cultural artefacts. He argues that a "linguistically informed awareness of our sources' textuality ... allows us an insight into the close textures of people's lives."18

The present article is similarly inspired by optimism about the alliance of cultural and social history. Like Sartori, I believe that law has produced historical archives that bear traces of the motives and visions of "little people," both

13 A. A. Kaderi, "A Mahdar from Hukeri in Karnataka," Epigraphica Indica: Arabic and Persian Supplement (Delhi: Archaeological Survey, 1972), 51-77, at 56-57.

${ }_{14}$ Muzaffar Alam and Sanjay Subrahmanyam, "The Making of a Munshi," Comparative Studies of South Asia, Africa and the Middle East 24, 2 (2004): 61-72; Rosalind O'Hanlon and David Washbrook, eds., Special issue on "Munshis, Pandits and Record-Keepers: Scribal Communities and Historical Change in India," Indian Economic and Social History Review 47, 4 (2010): 441615.

${ }^{15}$ Kathryn Burns, "Notaries, Truth and Consequences," American Historical Review 110, 2 (2005): 350-79.

${ }^{16}$ Bhavani Raman, Document Raj: Writing and Scribes in Early Colonial South India (Chicago: University of Chicago Press, 2012).

${ }^{17}$ Burns, "Notaries, Truth and Consequences"; Paolo Sartori, "Authorized Lies: Colonial Agency and Legal Hybrids in Tashkent, c. 1881-1893," Journal of the Economic and Social History of the Orient 55 (2012): 688-717. Note that these methodological aims are similar to that expressed by Guha in "Speaking Historically."

18 Paolo Sartori, "Introduction: On the Social in Central Asian History: Notes in the Margins of Legal Records," in P. Sartori, ed., Explorations in the Social History of Modern Central Asia (19thEarly 20th Century) (Leiden: Brill, 2013), 1-22 (his emphasis). 
users and agents of the law. Their recovery is essential to writing duly textured social as well as intellectual histories in relation to both the Mughal and British empires. In both cases, examining the vast marginalia of legal records with due attention to their coded form lets us uncover ordinary people's multiple expectations of law and legal process, and of their own place within it. Earlier works on law and colonialism in India found normative conflict arraigned along the lines of colonial state/Indian society. They revealed also how ideological claims of colonial law were inevitably compromised by the requirements of power and necessary alliances with local Indian power-holders. ${ }^{19}$ For a time, even those who did not view colonial law solely as the "state's emissary" ${ }^{20}$ only wrote of ways in which relatively powerless protagonists learned to use and utilize the legal norms of the dominant. ${ }^{21}$ More recently, however, scholars have highlighted the unquenched vitality of Indian and especially Indo-Islamic legal cultures. I myself have been inspired by Lauren Benton's concept of "jurispractice" 22 to examine how such legal cultures may have shaped the responses of the many Indian "experts" the colonial state recruited to man the lower rungs of its judicial machinery. In doing so, I have suggested that these petty agents not only "jockeyed" and navigated the conflicting jurisdictions of imperial law, but also thought clearly and rationally about how to reconcile them. ${ }^{23}$

The Indian mahzar-namas were recorded testimony documented by expert scribes at the edges of the legal process, and aimed principally but not exclusively at influencing legal outcomes. They were expressed in coded forms that derived from a complex Islamic, Persianate, and Indian heritage. Mahzar-namas tell us what people expected of the law, but they reveal much more: who the Indian users of Islamic law were and what they thought Islamic law consisted of; the multiple textual and professional vernacularizations of Islamic law; and the little experts who, in copying out their dry-as-dust legal documents from equally formulaic manuals produced by the best of their kind, furthered the culturally vital process of legal hybridization.

Recent projects focused on Qajar Iran and Russian-controlled Central Asia have studied legal forms as cultural artefacts. ${ }^{24}$ In general, though, legal forms

19 Singha, A Despotism of Law; David Washbrook, "Law, State and Agrarian Society in Colonial India," Modern Asian Studies 15, 3 (1981): 649-721.

${ }^{20}$ As Ranajit Guha did in "Chandra's Death," in Ranajit Guha, ed., Subaltern Studies V (New Delhi: Oxford University Press, 1987), 134-65.

${ }^{21}$ Shahid Amin, "Approver's Testimony, Judicial Discourse: The Case of Chauri Chaura," in Ranajit Guha, ed., Subaltern Studies V (New Delhi: Oxford University Press, 1987), 166-202.

${ }^{22}$ Lauren Benton, "Introduction" to "Forum on Law and Empire in Global Perspective," American Historical Review 117, 4 (2012): 1092-100.

${ }^{23}$ Nandini Chatterjee, "Hindu City and Just Empire: Banaras and India in Ali Ibrahim Khan's Legal Imagination," Journal of Colonialism and Colonial History 15, 1 (2014), http://muse.jhu. edu/journals/journal_of_colonialism_and_colonial_history/v015/15.1.chatterjee.html (online only).

${ }^{24}$ Christoph Werner, An Iranian Town in Transition: A Social and Economic History of the Elites of Tabriz, 1747-1848 (Wiesbaden: Harrassowitz, 2000); Sartori, "Authorized Lies"; and "Introduction." 
and formularies have received limited attention from scholars of Islamic law, and that, predictably, within Arabic-language, Muslim-majority contexts. Yet the genre of formularies and the forms of law were clearly important far beyond those contexts, and the mahzar-nama allow us to rethink the Islamic "textual habitus," 25 and the multiple and interacting cultural traditions of evidence-gathering, record-keeping, legal disputation, and invocation of authority that these documents bear traces of. In the Indian case, in many contexts most users were not Muslim and the political structures did not remain Islamic. There, the form in which disputants, with the help of their scribes, articulated their claims and complaints, and its marked similarities to (and differences from) comparable forms in Iran and Central Asia provide us a space in which to rethink the Indo-Islamic world and its specific forms of cultural hybridization.

\section{THE MAHZARS OF ISLAMIC JURISTS}

The vast and sophisticated documentary culture associated with practically every well-developed Islamic legal system represents a creative tension within Islamic law, which, according to the dominant line of juristic interpretation, frowns upon documents as a source of evidence in favor of the oral testimony of parties and/or reliable witnesses. Scholars debate whether the development of the body of literature collectively known as shurut or wathaiq (essentially, formularies), penned by jurists themselves and often contained within works of jurisprudence ( $f i q h$ ), represented a pragmatic disjuncture between doctrine and practice quietly countenanced by the jurists, ${ }^{26}$ or instead was another instance of Islamic jurists consciously attempting and managing to align jurisprudence with social needs and legal practice. ${ }^{27}$

Wakin, who held the former view, nevertheless noted that apart from the more fundamental contradiction regarding the acceptability of documentation, writers of classic works of shurut, being jurists themselves, were most careful to propose legally watertight formulae. In doing so, they kept within the boundaries of opinion within their own religious school (mazhab).$^{28}$ Hallaq further argues that the scribing of actual documents was undertaken by legally trained officials (not always the qazi) present in the courtroom, called shurutis. ${ }^{29}$ Ethnographic work conducted in the 1980s in Morocco revealed that while professional, state-appointed scribes called 'adl (Arabic plural 'udul),

\footnotetext{
25 This is Messick's formulation from Calligraphic State, 251.

26 This being the view of Joseph Schacht, An Introduction to Islamic Law (Oxford: Clarendon, 1964), 82; see also Wakin, Function of Documents, 4-10.

27 Wael Hallaq, "Model Shurūt Works and the Dialectic of Doctrine and Practice," Islamic Law and Society 2, 2 (1995): 109-34.

${ }^{28}$ On mazhabs, see Christopher Melchert, The Formation of the Sunni Schools of Law, 9th-10th centuries C.E. (Leiden: Brill, 1997).

29 Hallaq, "Model Shurūt Works," 115.
} 
supervised by qazis, displayed flexibility and cultural sensitivity, in their own view and that of those using their services everything was done "by the book"-here an official formulary written by the most prominent legal scholar of twentieth-century Morocco. ${ }^{30}$ In the Indian case, however, the professional, textual, and linguistic disjunction between the world of jurists and that of scribes was far greater, and in that creative space were produced artefacts such as the mahzar-nama, which bore many features distinctive of Indo-Islamic legal culture.

Before entering the world of Indian pensmen, ${ }^{31}$ we need to consider further the categories of legal documents conceived of by the jurists who wrote legal formularies, with a view to placing the mahzars (and the Indian mahzar-namas) within them. It appears from Wakin's survey that Islamic legal documents were conceived of by jurists, such as the ninth-tenth-centuries CE Egyptian Hanafi scholar Al-Tahawi (whose work she translated), as falling into two broad categories. One-shurut (or wathaiq) - included documents pertaining to "private" contracts such as marriage and its consequences, wills, charitable endowments, and sales. The other encompassed documents of public record-mahzars and sijills. ${ }^{32}$ Mahzars were supposed to be written records of proceedings in the qazi's court, and sijills records of the qazi's judgments. Mahzars and sijills often merited a chapter of their own at the end of works (or sections) on shurut, as was the case in Al-Tahawi's work. A near contemporary Baghdadi qazi, Muhammad b. Sama'a, composed a separate Book of mahzars and sijills (Kitab al-mahazir wa al-sijillat), and another, possibly contemporary Baghdadi qazi put it all together in a Kitab al-mahazir wa al-sijillat wa al-wathaiq wa al-'uqud. ${ }^{33}$

The largest compendium of Hanafi law ever produced in India, the imperially sponsored Fatawa-yi 'Alamgiri (also known as Fatawa-yi Hindiya), completed in 1692, contains a very large section ("book") on mahzars and sijills, as well as a separate one on shurut..$^{34}$ A perusal of these sections reveals the sense in which eminent Islamic jurists, which this book's Indian authors were, conceived of the mahzar and its functions, especially vis-à-vis legal proceedings.

${ }^{30}$ Leon Buskens, "Tales According to the Book: Professional Witnesses ('Udul) as Cultural Brokers in Morocco," in Baudoin Dupret, Barbara Baskens, and Annelies Moors, eds., Narratives of Truth in Islamic Law (London: Tauris, 2008), 143-60.

${ }^{31}$ On "pensmen," see Hayden Bellenoit, "Between Qanungos and Clerks: The Cultural and Service Worlds of Hindusan's Pensmen, c. 1750-1850," Modern Asian Studies 48, 4 (2014): 872-910.

32 Or mahazir and sijillat in the Arabic pluralized form. The concepts of private and public, which Wakin uses, may not be fully relevant before the formalization of Ottoman archival practices, although there is also debate about the novelty of Ottoman record-keeping. Wael B. Hallaq, "The $q \bar{a} d \bar{l}$ 's dīwān (sijill) before the Ottomans," Bulletin of the School of Oriental and African Studies 61, 3 (1998): 415-36.

33 Wakin, Function of Documents, 10-29.

${ }^{34}$ Sheikh Nizam and others, Fatawa-yi Alamgiri, Maulana Saiyid Amir Ali, trans. to Urdu (Lahore: Maktaba Rahmaniya, n.d.), vol. 10, 9-124; the section on shurut runs from 125-298. 
Helpfully, they open the section on mahzars and sijills with a brief explanation of the purpose of these documents, with injunctions on the best way to write them. With a heart-sinking recommendation of legal prolixity, the section begins, "The principle behind mahzars and sijills is, that testimony be stated in full and no satisfaction be taken in the abridged form." Thus, it recommends, based on a number of older authorities, that if it was only written in the sijill that "witnesses gave evidence according to (in support of) the claim," that sijill would be disapproved of or considered invalid. The recommendation was that, instead, both mahzars and sijills should record the names of the parties, their claims and counter-claims, the precise testimony rendered, and the minute details of (any) property in dispute, even if repetitive, leaving absolutely nothing to doubt. The Fatawa-yi 'Alamgiri's authors further prescribe that mahzars and sijills record that the correct procedural order (of declaration, response, seeking evidence, and so on) had been followed and a strict formula of declaration maintained. This was so that recorded testimony ran no risk of being rejected in future due to difference of opinion among jurists (ikhtilaf), which was a key concern of shurut writers. ${ }^{35}$ Each of these stipulations is followed by several examples derived from juristic authorities of imperfect and perfect forms of recording testimony.

These two documentary forms were clearly intended to overlap in content: mahzars were meant to be the record of court proceedings, including claims, counter-claims and testimony, and sijills were to record the qazi's judgment based on the former and contain a full reiteration thereof. The several intertwined examples over the next hundred pages of the Fatawa-yi 'Alamgiri (with a mahzar and a sijill for every type of claim) demonstrate the functions of the mahzars, as they were distinct from but also overlapped with the sijills. For example, with reference to a claim of outstanding debt, it is recommended that the mahzar begin with the name of God and then state: "In the court of justice in the city of Bukhara, there came in front of qazi so-and-so (stating their name, genealogy, and titles), who is appointed judge among the people of Bukhara by such-and-such prince, on such-and-such date, month, and year. ..." This was to be followed by the names (including father's name) and genealogies of the plaintiff and defendant, followed by the claim. This could be followed by confession (iqrar) by the defendant of the veracity of the claim, or by denial (inkar), in which case the plaintiff would produce witnesses and the document would record their acceptance and appointment by the qazi. After a curiously dramatic process of eliciting testimony from these witnesses (more about which later), the mahzar would record their names, appearance, genealogies, and domiciles, the steps of the process by which testimony

\footnotetext{
35 Ibid., 9-11. On ikhtilaf, see Wakin, Function of Documents, 32-34; Hallaq, "Model Shurūt Works," 129-31.
} 
was elicited, verified, and recorded, and finally the testimony itself. ${ }^{36}$ The sijill on the same claim of debt would contain exactly the same record up to this point, and then proceed to describe the procedure by which the judge established the acceptability of the witnesses and their testimony. The judge would then invite the plaintiff to produce any documents, failing which he would deliver the judgment and record it in full in the sijill. The sijill would also record its own incorporation in the court register and the date of same, together with an attestation of the qazi on the left-hand side of the sijill that it had been scribed by the court clerks in accordance with his orders. The sijill, therefore, incorporated and transcended the mahzar in the jurists' description of Islamic documentary forms.

The function of the classical Islamic form, the mahzar, appears to have been the production of documentary records of claims and related testimony in legal disputes heard by qazis. They might be used as evidence in the dispute at hand or in a future one, thus representing a pragmatic and juristically approved procedure for overcoming difficulties of procuring verbal testimony over distance and time. While perhaps resting on a basic contradiction between the doctrinal insistence on verbal testimony and the need for documentation, this documentary form was nevertheless elaborated and refined by the jurists themselves with the aim of aligning other aspects of doctrine with court practice. Thus the seventeenth-century Indian writers of the Fatawa-yi 'Alamgiri were concerned with instructing an audience that they assumed to be composed of their peers, and, working as qazis, with how to best record claims and testimonies produced in their court so that they were admissible as evidence in disputes under their own consideration or in future ones heard by other jurists and/ or judges. These were instructions for producing notarized and judicable truth, a guide for legal experts on how to apply their doctrinal knowledge to translate a specific dispute and related statements into the standard, doctrinally approved forms of Islamic law.

THE MAHZARS OF KINGS, SAINTS, AND TOWNSMEN

Kings and saints, as we know, often used terms related to Islamic law, but gave them new meanings that transcended jurisprudence. ${ }^{37}$ From the twelfth century onward, Muslim kings of Delhi and their subordinates and/or rebels found various occasions for soliciting the opinions of jurists ('ulama) on the righteousness of different cultural and religious practices, and indeed on their own status, through collective declarations also known as mahzars. In some cases these declarations were scribed as physical documents or other textual artefacts such as inscriptions on stone pillars. While such declarations shared

\footnotetext{
36 Sheikh Nizam and others, Fatawa-yi 'Alamgiri, 11.

37 Muzaffar Alam, The Languages of Political Islam: India, 1200-1800 (London: Hurst \& Co., 2004).
} 
little in terms of the procedures and formulae associated with the mahzars of Islamic jurists, they did hold in common their deliberative, declarative, and public nature. They also aimed at a similarly authoritative statement of facts and rights, even if they were literally written much larger than the typical legal document.

Scholars studying the Turkish and Afghan dynasties that ruled northern India from the thirteenth to sixteenth centuries, now collectively known as the Delhi Sultanate, have referred to Persian-language discourses (malfuzats) and other literary sources, which record the summoning of multiple mahzars by the slave-turned-Sultan Shams al-din Iltutmish (r. 1211-1236) and his successors. These kings utilized mahzars to examine the personal and/or political uprightness of particular Sufi saints, or the acceptability of certain Sufi ecstatic practices (specifically, the sama). Attendees at these gatherings appear to have been jurists ('ulama), Sufi teachers (mushaikh), and nobles, and they took place in various locations including Delhi's Friday mosque. The most eminent saints were said to have been exonerated by their peers and adored by the righteous king, while others were deemed treacherous and executed on the spot. ${ }^{38}$

In contrast to these hagiographic accounts, which have left no documentary traces, we have an (in)famous document reported and purportedly reproduced by 'Abd al-Qadir Badauni, the famously acerbic courtier of the third and most politically innovative Mughal emperor, Jalal al-din Muhammad Akbar (r. 1542-1605). In his secret account of the many un-Islamic improprieties committed by this emperor, Badauni mentioned how, in the year $1579 \mathrm{CE}$, Akbar engineered the production of a document whereby the 'ulama at his court gave the king the ultimate right to make decisions when they themselves failed to reach a conclusion. Presented by Shaikh Mubarak, the father of Akbar's friend, biographer and courtier Abul Fazl, this document has been seen as an attempt by Akbar to usurp and transcend the authority of jurists, and wrongly referred to as the "Infallibility Decree." ${ }^{39}$ In fact, the document was not a decree, in which case it would be called a farman. Badauni, who one expects would know the difference, called it a mahzar. In it, the selfdescribed principal 'ulama of Akbar's court declared that they had come to a certain decision, for the following reasons: Hindustan had become a land of peace and many learned men from Arab and non-Arab lands ('arab and 'ajam) had immigrated there; the king's status was higher in the eyes of God than that of those qualified to debate on Islamic law (mujtahids); the Quran and verified traditions (hadith) instructed people to obey the ruler; and their

38 Khaliq Ahmad Nizami, Salatin-i Dihli ke mazhabi rujhanat (Delhi: Idarat-i Adabiyat-i Dilli, 1981), 121-22, 209, 315-16.

39 The first historian to name it as such was Vincent Smith. For perhaps the earliest criticism, and the argument that it was essentially a political response to external competition and internal threats, see F. W. Buckler, “A New Interpretation of Akbar's 'Infallibility' Decree of 1579," Journal of the Royal Asiatic Society of Great Britain and Ireland 4 (1924): 591-608. 
own reasoning supported it. Given all these reasons, and because Akbar was a just and wise king, they had decided that if the mujtahids could not agree on a religious question, whichever opinion the king chose for the benefit of the nation would be binding on them all. They also declared that the king was entitled to make new rules, provided these were in line with the Quran and in the nation's best interests. ${ }^{40}$

This mahzar followed close on the heels of the execution of a foulmouthed Brahmin on the orders of the chief Qazi, 'Abd al-Nabi, despite Akbar's disapproval of the action. The jury is still out on whether the incident represented a logical stage in the development of Akbar's tolerant religious policy in which he tried to release himself from the stranglehold of inflexible 'ulama, ${ }^{41}$ or was instead a failed last-ditch attempt to placate the 'ulama and claim legitimacy on the basis of, and not despite, Islam. ${ }^{42}$ The use of the mahzar form and its precise contents favor the second explanation, and it is no surprise that as Akbar's transcendental ideology of royal absolutism evolved, this document, in which jurists declared the king's rights and privileges according to Islamic law, was found to be inadequate.

In contrast to these somewhat apocryphal stories, in which the rights of kings and saints were declared by adoring or arm-twisted subordinates, we have more concrete assertion of both royal privilege and collective endorsement from the same period, recorded in a stone inscription in a village called Hukeri in north Karnataka in southern India. Its text, self-described as a mahzar, was written in both Persian and Marathi, on two separate stones, both in the year $1583 \mathrm{CE}$. It says that the mahajanan (great people, including the qazi) and balutian (village functionaries) of the qasba (town) of Hukeri gave in writing that they had given a certain portion of land for the upkeep of a water-storage tank and a guesthouse. Both of these were erected by a local officer named Mansur Khan, who worked for the fief-holder of the region, who was in turn affiliated to the south Indian state of Bijapur. ${ }^{43}$ So this was a grant made by a local noble, endorsed by a huge range of local stakeholders that included the qazi and salar (possibly garrison commander), but also village and provincial record-keepers (kulkarnis), village headmen (patels), and the heads of various artisanal castes such as gardeners, blacksmiths, tailors, and astrologers. Sumit Guha has studied this mahzar, and

\footnotetext{
40 'Abd al-Qadir Badauni, Muntakhab ut-tawarikh, W. N. Lees and Ahmad Ali, eds. (Calcutta: Bibliotheca Indica, 1865), 171-72.

41 S.A.A. Rizvi, Religious and Intellectual History of the Muslims in Akbar's Reign, 2d ed. (Delhi: Manohar, 1975), 141-74.

${ }^{42}$ Iqtidar Alam Khan, "The Nobility under Akbar and the Development of His Religious Policy," Journal of the Royal Asiatic Society of Great Britain and Ireland 1/2 (1968): 29-36.

43 Kaderi, "A Mahdar from Hukeri” (my emphasis). A very similar collective grant was recorded in a mahzar scribed in 1724 in Ahmedabad; Z. A. Desai, "Mahzar-An Important Source for Administrative History," Indian Historical Review 25, 1 (1998): 16-28. Being based on a sample of the declarative type only, Desai's attempt at a typology was inadequate.
} 
used it to emphasize the uniquely assertive and resilient caste structures that worked as civil institutions in the region, holding centralizing state power at bay in a way that he speculates was impossible in northern India. ${ }^{44}$

The power of the local community and its intermingling with Islamic state institutions in the Marathi-speaking and writing ${ }^{45}$ southwestern parts of India also left traces of itself in another prolific documentary form also known as mahzar, which bore surprising resemblances with the jurists' mahzar. This resemblance is all the more striking when we are attentive to the institutions that issued them. The earliest Marathi mahzar that I have learned of is from the year $1333 \mathrm{CE}$ (Saka 1255) and is about a grant of a share in land taxes (sardeshmu$k h i)$ rather than the adjudication of a dispute as such. This mahzar, in the same vein as the one from Hukeri, declares, "As per the application made by Dadaji son of Reuji Hande Deshmukh of Junnar district (pargana), Sayaji, son of Gomaji Kadu, has been allocated the sardeshmukhi of eighty-four villages of Chakan district." The grant was made by a thirty-six-strong assembly (majlis), of which thirty-five were military officials (lashkari huddedar) and the other a village headman (deshmukh). Twelve of the thirty-six were Hindus. At the top of the document is a Persian summary of the subject-matter, followed by a date and a detailed list of the members of the majlis that acted as the authoritative body. After this come full details of the matter in question, and the final decision. Apart from the summary in Persian at the top, the entire document is written in heavily Persian-infused Marathi, in the scribal Modi script. Endorsements are arranged on the right and bottom margins, and strikingly, signatories (here the members of majlis) added professional symbols such as sword, scimitar, or measuring scales. ${ }^{46}$

The form of the majlis, and its chosen form of documenting its decisionthe local version of the mahzar-persisted in the Marathi-speaking regions, although the composition of the majlis evolved over the next four centuries. They survived the transition from the reign of the Adilshahi Sultanate (Bijapur) to the Maratha Empire that was created by Shivaji through rebellion against both Bijapur and the Mughals. Compared to the very early form we have just seen, later iterations of the majlis included a greater variety of officials, including the local qazi (this part collectively called the diwan) and many more nonofficial caste and community leaders (collectively called the got). ${ }^{47}$ For example, the signatories of the 1583 mahzar from Hukeri reflected this "mature" form of the majlis. Similarly constituted bodies also adjudicated disputes, as noted in a letter written by the head judge of the Maratha Empire

44 Sumit Guha, Beyond Caste: Identity and Power in South Asia, Past and Present (Leiden: Brill, 2013), 66-67.

45 And possibly also Gujarati; see Desai, "Mahzar."

46 V. T. Gune, The Judicial System of the Marathas (Poona: Deccan College, 1953), 141-42.

47 Ibid., 135-36; Gune analyzed 161 mahzars from between 1300-1800, and a further 210 documents from 1650-1800 that include several mahzars. 
(the nyayadhish) in 1698, confirming the decision taken by a got after considering the written accounts (karina) of two priests competing over the entitlement to officiate at a holy site. The decision was referred to as a mahzar. ${ }^{48}$

The Marathi mahzars, which could record executive orders, but also adjudicative decisions, thus lay within a more widely used spectrum of declarative forms that appeared in northern India from at least the thirteenth century. The uses of such declarative mahzars ranged from jurists making a public evaluation and declaration about the rights of kings, to townsmen swearing to uphold a grant of land made for a charitable purpose. In this connection, it appears that there emerged a specific tradition of collective declaration of right by conjoint state functionaries and community leaders, which may have derived from or resonated with older practices of collective deliberation and decision-making. The name mahzar, on the other hand, connected this documentary form and practice with the history and trajectory of the expansion of Islamic (that is, Delhi Sultanate-derived) state forms in the western and southern parts of India.

Ironically, mahzar-writing survived and flourished under the selfconsciously Brahmanical Maratha Empire of the seventeenth century. Gune, the scholar who studied them most meticulously, suggested that Marathi adjudicative mahzars, in particular, were very similar to the legal form called mahzar in the Fatawa-yi 'Alamgiri, if leaning somewhat in the direction of sijills. Gune suggested that in including endorsements the Marathi mahzars were distinct from Islamic mahzars and instead indebted to royal decisions (jayapatras; literally "letters of victory") recommended by Sanskrit (therefore Brahmanical Hindu) dharmashastras and their commentaries. ${ }^{49}$ Whether or not this was the case (and it is beyond my linguistic ability to evaluate), endorsements in the form of witness clauses were an integral part of many other Islamic documentary forms, especially those recording interpersonal exchanges of value and obligations (legal deeds). ${ }^{50}$ Endorsements that were modelled on such witness clauses, but undirected by a legal functionary or institution, distinguished the north Indian (Hindustani) form of the mahzar. They suggest that the recording of judiciable truth may here have become part of the documentary culture of interpersonal transactions, stepping beyond the authority of not only the qazi, but any stable corporate entity such as the majlis.

FROM MAHZAR TO MAHZAR-NAMA: THE MUGHAL AVATAR OF AN ISLAMIC DOCUMENTARY FORM

Mughal mahzars —or to specify our legal documentary "type," mahzar-namas —unlike the jurists' mahzars but also unlike the Marathi ones, were essentially legal documents of testimony. They, too, possessed a unique form, which

\footnotetext{
48 Ibid., 274.

49 Ibid., 76-80.

50 See note 9 , above.
} 
incorporated features shared with Persian and Central Asian documentary forms but also distinctive formulae and linguistic and scribal features. They, too, were used for a wider range of functions than the mere recording of testimony in connection with specific legal disputes. These functions connected them to a broader Indo-Islamic world in which collective declarations of right connected law inseparably with politics, and the adjudicative role of the qazi with the assertive role of the community.

Among the distinctive features of the Mughal mahzar-nama was the form of the document itself, beginning with the opening formula. Whereas the jurists of the Fatawa-yi 'Alamgiri recommended beginning a mahzar with a simple invocation of the name of God, Mughal mahzar-namas usually began with Sura 2: 283 from the Quran: "La takatamu al-shahada wa man yaktumuha fa innahu athimun qalbuhu" ("Conceal not evidence; for whoever conceals it, His heart is tainted with sin"; Yusuf Ali's translation). This stringent exhortation to observe the Islamic obligation of rendering testimony ${ }^{51}$ was followed by this demand stated by the plaintiff in Persian, in the first person: "Sawal mi kunam/kunim wa gawahi mi khwaham/khwahim" (I/We ask, and want evidence). Another formula for beginning a Mughal mahzar-nama was, "Bai's- $i$ tahrir-i in sutur anke, manke..." (The reason for writing these notes is that, I, who...). Note that in either case, it was the affected party or claimant, not the qazi, who ostensibly sought the supporting testimonials.

This was indeed how members of a family of Muslim legal scholars, contemporary to Sheikh Nizam and the compilers of the Fatawa-yi 'Alamgiri, began their own mahzar-nama, which they wrote in $1692 \mathrm{CE}$. The family produced an eminent lineage of Sunni 'ulama, who went on to establish the famous seminary of Firangi Mahal in Lucknow and create a distinct syllabus of study known as the Dars-i Nizamiyya. ${ }^{52}$ Like many such scholars, this family held and enjoyed a grant of tax-free land from the Mughal emperor, known as madad-i ma'ash, and as in many such cases, they suffered from the jealousy of local landlords or zamindars. ${ }^{53}$ In the middle of the day, on 19 May 1692 , when the head of the family, the Maulavi Qutb al-din, was busy as usual in

51 On the Islamic legal obligation of testifying, except in cases involving fixed punishments ( hadd), see James Baldwin, "Prostitution, Islamic Law and Ottoman Societies," Journal of the Economic and Social History of the Orient 55, 1 (2012): 117-52; Rudolph Peters, Crime and Punishment in Islamic Law: Theory and Practice from the Sixteenth to the Twenty-First Century (Cambridge: Cambridge University Press, 2005), 12-19.

52 Francis Robinson, The 'Ulama of Farangi Mahall and Islamic Culture in South Asia (London: Hurst, 2001). I am grateful to Professor Robinson for providing me with a copy of the Firangi Mahall mahzar-nama. A blurred facsimile and transcription of the text is available in Muhammad Reza Ansari Firangi Mahali, Bani-yi dars-i nizami: Ustad al-Hind Mulla Nizam ud-din Muhammad Firangi Mahali (Lucknow: U.P. Urdu Academy, 1973), 21-34.

53 On the conflict between local landlords and grant-holding scholars, see Muzaffar Alam, The Crisis of Empire in Mughal North India: Awadh and the Punjab, 1707-48 (Delhi: Oxford University Press, 1986), 117-22. 
teaching students and casual visitors, a group of armed men surrounded the house, dug under the walls, and attacked the Maulavi and his students and guests. The Maulavi died of seven sword slashes, a spear wound, and a gunshot. Also killed were two students from another center of learning, Sandila, who happened to have come there for their graduation. The attackers then burned the valuable library, which included many books written by the Maulavi himself, molested women of the family, and made off with the Maulavi's corpse, his youngest son, and the head of one of the men killed. Eventually, worthies of the assailants' village intervened and had the boy released, the head buried, and a mutilated corpse returned for a decent burial.

These events were narrated by the mahzar-nama itself, which began, as the distinct form required, with the Quranic verse prohibiting the concealment of testimony and with the sentence, "We ask and we want testimony, we who have been oppressed (sitam rasidgan) ${ }^{54}$ : Muhammad Said and Nizam al-din Ahmad and Muhammad Reza, sons of Maulavi Shaikh Qutb al-din, residents of qasba Sehali, sarkar Lucknow subah Awadh. ..." They appealed for this testimony to the "Qazis of Islam and benevolent scholars or mystics (shaikhs) and members of the public, big and the small, of these regions (to whom) this matter is known and evident." The text then proceeded to describe the spirituality, knowledge, and achievements of the murdered scholar, the events of the day, and the damages and harm suffered, including the contents of the scholar's destroyed library. The document itself asked for nothing in particular, except evidence that the claims were true, that an injury had been suffered. We do know that the Firangi Mahal mahzar-nama was effective-it was presented to the emperor 'Alamgir himself, who compensated the family with a grant of a house and property in Lucknow. ${ }^{55}$

This document, then, served more as a record of wrongs suffered and an implicit petition to royal authority rather than as documentation of evidence in support of a specific legal dispute in a qazi's court. It was testimony, of course, and also testimony authenticated by the marginal endorsements that physically framed the central narrative. In fact, matters grew really lively in these documents' margins. As with all other writers of mahzar-namas, the 'ulama of Firangi Mahal depended for the success of their appeal on the gathering of short endorsements, complete with seals and signatures of such signatories. These endorsements in the top, right, and bottom margins could be as short as "bayan sahih ast" (the account is true) or "gawah shud" (it is witnessed), or the signatories might provide longer summaries of the events and entitlements. The margins of the Firangi Mahal mahzar-nama held approximately seventy-five such signed endorsements, attested with almost as many seals.

\footnotetext{
54 Sic. Grammatically it should have been sitam rasidegan.

55 Robinson, 'Ulama of Farangi Mahall, 106.
} 
At least three of the signatories were qazis, but in terms of neither size nor their placement on the document were their endorsements given any precedence over those of the others who also clamored to assert the truthfulness of the central narrative's claims.

This and other Mughal mahzar-namas were comparable with, but did not entirely replicate, other forms of recorded testimony from the wider Persianate world. In early nineteenth-century Bukhara, for example, Persianlanguage mahzars were in evidence, but they were bills of plaint scribed by jurists on behalf of the plaintiffs and addressed to rulers, and they sought the restitution of specific rights or recompense for specific injuries. They included no marginal attestations. ${ }^{56}$ From later, Russian-controlled times we have shahadatnamas from Bukhara, documents that recorded testimony rendered by witnesses who had come to a specific courtroom and testified to past transactions for which the original documents could not be found, most commonly the creation of a waqf, or pious endowment. Although produced under Russian procedural pressure, which required adequate documentation in order that a waqf could be upheld, shahadatnamas are said to conform to older Islamic legal models from the region. ${ }^{57}$ If so, Central Asian forms of testimony seem never to have admitted marginal endorsements by non-jurists. They appear to be far more cut and dried: people came to court to attest to the facts of a certain matter, which were evaluated and validated by a qazi, who recorded the statements and added his notarial seal. The result was a legal instrument of probative value.

From nineteenth-century Qajar Iran, on the other hand, we have a form of document called ishtishhadnama, which is closer in form, appearance, and possibly function to the Indian mahzar-namas. ${ }^{58}$ Ishtishhad means "seeking of evidence." For one example, evidence was formally sought and recorded in such a document scribed in 1893-1894 by the inhabitants of the town of Zanjan in northwestern Iran, in which they recorded the plundering of waqf property by the horsemen of a certain 'Ali Bayg. Like the Indian mahzar-namas, this Iranian document recorded testimony by those afflicted (in this case, by a certain wrongdoing), without the immediate, or at least obvious context of a court proceeding. Also, the testimony lacked the tone of finality rendered by a single authoritative validation by a qazi. Instead, it was endorsed by multiple short statements to the effect that the testimony recorded was true. All these

\footnotetext{
56 I am grateful to Paolo Sartori for showing me samples of such documents.

57 Paolo Sartori, “Colonial Legislation Meets Sharī'a: Muslims' Land Rights in Russian Turkestan," Central Asian Survey 29, 1 (2010): 43-60, esp. note 29; Phillip Reichmuth, "Lost in the Revolution': Bukharan Waqf and Testimony Documents from the Early Soviet Period," Die Welt Des Islams 50 (2010): 362-96.

${ }^{58}$ In fact, documents called ishtishhadnamas occur in Indian collections, too, especially those of the nineteenth century; the possibility of a renewed and later stage of mutual influence remains open to further research.
} 
statements bore small seals of private individuals and were scribed around the margins of the document. ${ }^{59}$ At face value, at least, this document, like the Indian mahzar-namas, appeared to be a collective effort to assert the truth of a matter, rather than the final word on the subject. Unlike the Indian mahzarnamas, however, the Iranian document made no effort to validate itself with reference to the Quran, and included no Quranic formula of exhortation to render testimony. This Indian genre is even more striking when we consider that the vast majority of those authoring the Indian mahzar-namas would not have been Muslims.

Mughal mahzar-namas did one more thing, which renders them unique even among the comparable genres of documents from the Persianate world. They exhibited, nay flaunted, an aspect of Indian socio-cultural life that strikes most outsiders as remarkable: a vibrant multilinguality. While the central body of the texts is written in Persian, and sometimes endorsements are in rougher, cursive Persian (as in the Firangi Mahal mahzar-nama), in many mahzar-namas witnesses endorsed the testimony with brief comments and signatures in a variety of Indian languages and scripts, depending on their background. It was also usual for people to jointly sign and seal a common statement of endorsement, and those who thus grouped themselves often signed in the same language and script. In many cases, people also added their valued symbols for authentication. While I have never found one on a mahzar-nama, other legal documents with collective endorsements even within the Purshottam Das "family papers" bear the Hindu symbol of swastika. ${ }^{60}$

To return to the jurists for a moment, the Indian authors of Fatawa-yi 'Alamgiri, despite their habit of referring to Bukhara as the model city in which their qazi sat, did display their awareness of the special conditions produced by India's linguistic diversity and the disjuncture between oral and written cultures, which they correctly envisaged as being matter of course in Indian courts. Thus they said that once the plaintiff had produced witnesses, the qazi should have their testimony written down on a piece of paper in precise Persian formulae. This would then be read back to them by court officials, who were also required to indicate the precise parties and documents when these were mentioned in the testimony. The witnesses were then required to state that they did indeed agree to testify as had been written down and read out to them, from beginning to the end, and sign their names in the appropriate places. $^{61}$ The incorporation of such multilingual dramatic interludes in the court proceedings, and the recognition of the necessary interface between

\footnotetext{
59 “Testimony from Zanjan and Khamsah," 1893-1894, http://www.asnad.org/en/document/ 667/ (last accessed 18 July 2015). I am indebted to Christoph Werner for directing me to this document.

60 An example is in the Hiba-nama or gift-deed made out by Musammat (Madam) Goran, Persian document no. 2738/8, National Archives of India.

61 Sheikh Nizam and others, Fatawa-yi 'Alamgiri, X, 11.
} 
documentation and verbal utterance, clearly reflected the jurists' recognition and expectation that litigants would not be literate (or even orally fluent) in the language of jurisprudence (Arabic), but rather that of administration (for Mughal India, this being Persian).

In actual mahzar-namas produced in Mughal India, the disjuncture and associations of language went much further beyond a bilingual jurisprudential-administrative/Arabic-Persian divide. While the eminent imperial jurists did not deign to recognize the fact, most litigants in Mughal India were unlikely to be adequately fluent even in Persian. The multilingual and multi-scribal endorsements on the margins of the Indian mahzar-namas, demonstrate that working qazis in the Mughal Empire were fully willing to accept endorsements to testimony in multiple Indian languages and to accommodate multivalent symbols of value ranging from Quranic verses to swastikas. Indeed, as we have seen that when families of eminent jurists themselves needed to record their sufferings and seek redress they turned to this unique Mughal form rather than any form recommended by their professional peers.

JURISPRUDENCE OR BELLES-LETTRES? MAHZAR-NAMAS IN MUNSHATS

If Mughal mahzar-namas were a regionally, historically specific, and so popular development of the Islamic documentary form of mahzar, what was their model? For however exuberant a Mughal mahzar-nama was, it still conformed to a standardized form. In doing so, it resembled a body of legal formularies, although it was clearly distinct from those contained within the books of jurisprudence ( fiqh) such as the Fatawa-yi 'Alamgiri. Such formularies did exist, and they were produced by and for a different social and professional class consisting of professional scribes or munshis. These were not legal experts but rather, at their best, linguistic and literary stalwarts who offered an ideal of belles-lettres that many cultivated men in Mughal India aspired to. Both their professional and confessional status (munshis were often, and in fact, classically, not Muslims) indicate the historical transition of an Islamic device into the social world of multi-religious Mughal India.

Some of the most exciting recent works in Mughal history has been on the education, cultural world, and political visions of the professional secretarial class - the oft-denounced but ubiquitous munshis. ${ }^{62}$ The art of the munshi was contained in two genres of texts, the first being munshats and the second siyaq-namas (or khulasat al-siyaq). ${ }^{63}$ Siyaq is a Persian form of accountancy using special codes, but munshats were a more complex genre, consisting of model prose compositions generically designated insha. Insha is a hard category to translate, although it is commonly rendered as "letters," or "epistolary compositions." That is because the appellation also applied to prose writing of

62 See note 14 .

63 An example is the anonymous khulasat al-siyaq, Add. 6588, British Library, London. 
various kinds, ranging from essays on the beauties of spring to model legal forms, the latter being our concern here. ${ }^{64}$

One of the earliest writers of exemplary munshats in India was the most celebrated Indo-Persian poet of all time, Amir Khusrau Dehlavi. ${ }^{65}$ This thirteenthcentury Sufi poet and courtier of Sultan 'Ala al-din Khalji composed, among many other works, the A 'jaz-i Khusravi [Miracle of Khusrau], a work in five sections (risalas), of which Risala II, sub-section (Khat) I consisted of "imitations [models] of orders, letters of judges, Shaikhs, Saiyids. ..." This did not really contain any legal formulae, only impossibly long letters of appointment for judges and petitions of the oppressed to, against, or in support of judges. As was typical of the sabk-i Hindi (lit. "Indian style [of Persian writing]"), ${ }^{66}$ this work was concerned with demonstrating the usage of complex figures of speech, as it displayed several times in a single hypothetical document, and it is unlikely that it served as a functional formulary. ${ }^{67}$ Working almost a century later, Mahmud Gawan (1411-1481), the Persian courtier of the Bahmani sultans of Bidar in north Karnataka, ${ }^{68}$ compiled his own munshat, the Riyaz al-insha, which has been accorded greater recognition than Khusrau's work as marking the beginning of the munshat form of writing in India. Despite Gawan's role as the chief minister (wakil-i sultanat) of the Bahmanis, Riyaz al-insha included no legal forms. ${ }^{69}$ Neither did the writing of India's most celebrated munshi ever, Akbar's courtier Abul Fazl, whose tome contained mainly diplomatic missives. ${ }^{70}$

In contrast, north Indian munshats produced from the seventeenth century onwards began to contain a section of legal forms as a matter of routine. The Munshat-i Namakin, compiled by the imperial employee Saiyid Abu al-Qasim, alias "Namakin" (d. 1609/10), contained forms of legal documents (qibala), alongside forms for diplomatic letters, royal orders, petitions, and prescriptions. ${ }^{71}$ Another work, the Insha-yi Harkaran was composed around 1625 by Saiyid Abu al-Qasim's younger contemporary, Harkaran Das Kambuh, said to be the first known Hindu whose munshat was copied as a model by later writers. ${ }^{72}$ This

${ }^{64}$ Riazul Islam, A Calendar of Documents on Indo-Persian Relations (Tehran: Iranian Culture Foundation, 1979-1982), 1-37, 1.

65 Sunil Sharma, Amir Khusraw: The Poet of Sufis and Sultans (Oxford: Oneworld, 2005).

${ }^{66}$ S. R. Faruqui, "Stranger in the City: The Poetics of Sabk-i Hindi," Annual of Urdu Studies 19 (2004): 1-59.

${ }^{67}$ Amir Khusrau Dehlavi, A jaz-e Khusravi (Lucknow: Nawal Kishore, n.d.), Risala II, Khat I (no page numbers).

${ }_{68}$ Richard M. Eaton, A Social History of the Deccan, 1300-1761: Eight Indian Lives (Cambridge: Cambridge University Press, 2005), 59-77.

69 One of the manuscripts of this work is Add. 1739, British Library, London.

${ }^{70}$ Mukatabat-i Allami (Insha-yi Abul Fazl): The Letters of the Emperor Akbar in English Translation (New Delhi: Munshiram Manoharlal, 1998).

${ }^{71}$ Ishtiaq Ahmad Zilli, The Mughal State and Culture 1556-1598: Selected Letters and Documents from Munshaat-i-Namakin (New Delhi: Manohar, 2007), ch. 7, 331-70.

${ }^{72}$ Muzaffar Alam, "The Pursuit of Persian: Language in Mughal Politics," Modern Asian Studies 32, 2 (1998): 317-49, at 327. 
book contained an entire section on khatut wa qibala-yi shari 'a (rendered "Of writing the contracts of law" by the first British translator). The book had seven sections:

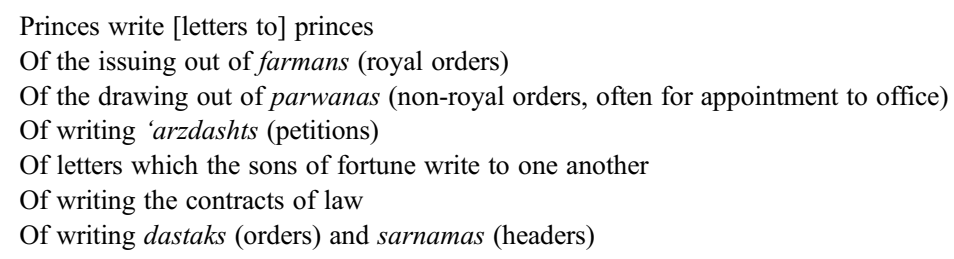

The sixth and seventh sections included-alongside model legal forms for sale, mortgage, manumission (of slaves), security bonds, court orders, service certificates, passports, and court orders - a self-described mahzar-nama, wrongly translated by Balfour as "summons."73 This model mahzar-nama did not contain the Quranic verse, but otherwise ran quite like the documents we have discussed so far. It began, "The oppressed slave [I], Abu al-Khair, son of 'Abd al-Rahim Quraishi, does ask and request evidence with regard to this. ..." It then narrated the injury sustained: that a certain Ghiyas had illegally usurped a garden that belonged to the writer of the mahzar-nama, killed his elder brother, and threatened him with murder, until the poor Abu al-Khair had to flee with his life. The mahzar-nama ended with the standard appeal from Abu al-Khair, "All those that may have information about this matter may for God's sake ('and Allah) write their testimony or permit it to be written, so that az sawab bi bahra nabashad (that they may not be deprived of the good fortune of [acquiring] due reward)."

Another model mahzar-nama occurs in a mixed-genre eighteenth-century text written by a disgruntled government official in Delhi called Shakir Khan. He not only complained through his history (tarikh) about the political and social decline that he thought he saw, but recommended curative principles of statecraft. The Tarikh-i Shakir Khan-i also contains a massive appendix of legal documents (qibala-yi shari'a) and orders (parwanajat) of appointment to service and the like. ${ }^{74}$ This appendix contains a long model document, which begins, "The declaration of a mahzar: that since the ayat-i karim (the noble verse) [says], conceal not evidence; for whoever conceals it, His heart is tainted with sin, and concealing of testimony is for this reason forbidden." Then the imaginary author of this mahzar-nama, called Muhammad Javed, narrated how he frequently travelled abroad and therefore had let a certain Afghan, who had been looking desperately for a place to live in together with his wife

73 Insha-yi Harkaran, Add. 26,140, British Library, London; translated by Francis Balfour as The Forms of Herkern (Calcutta: n.p., 1781), 184-87.

74 Tarikh-i Shakir Khani, Add. MSS 6585, British Library, London, ff. 122a-155a. The mahzarnama within this section is reproduced in Ibn Hasan, The Central Structure of the Mughal Empire and Its Practical Working up to the Year 1657 (London: Oxford University Press, 1936), 367. 
and children, stay in his house. However, on returning from his trip, Muhammad Javed found the said Afghan refused to vacate the property. And so the fictitious Muhammad Javed appealed to all, the great and small, of the qasba (town) of Bilgram, to endorse the truth of what he had described, requesting they sign their names below the document, "so that they may be rewarded by God and thanked by men (ke 'and Allah majur wa 'and al-nas mashkur)."

Thus in the hands of Persian-literate scribes, the most exalted of whom were full participants of the Perso-Islamicate courtly culture crowned by the Mughals, the legal form of recording testimony called mahzar took a historically distinct shape. Drawing on their experience in the world of diplomacy and administration rather than jurisprudence, these men created a documentary form for recording claims and injuries by myriad, legally untrained individuals, for purposes of legal action, but not limited to it. The form was used by the 'ulama of Firangi for petitioning, not disputation, and by Purshottam Das of Malwa to notarize his entitlements, especially in the presence of rival claimants and in the absence of adequate title deeds. But what is clear is that this hybrid legal form that sought testimony in the voice of the protagonists, and with direct reference to the Book of Books, was the one that even jurists turned to when it came to real-life trouble in Mughal north India.

\section{LAYERED EMPIRES: MAHZARS IN THE WAKE OF THE MUGHALS}

As the Mughal Empire went into steep decline in the early eighteenth century and a number of military-political aspirants to imperial status jostled to replace them in various parts of the Indian subcontinent, the mahzar-nama acquired a further lease on life. Among the novel political formations that embraced the legal and administrative forms of Mughal rule were the multiple Sikh warlord-led misls, which by the late eighteenth century had replaced Mughal administration in the province of Punjab. Central imperial rule had fragmented through a combination of peasant rebellions, badly handled sectarian conflicts, economically hamstrung administration, and foreign invasion. ${ }^{75}$ At the eastern edge of the Mughal Empire there was, of course, another major political presence in the English East India Company, which between 1757 and 1765 had managed to practically conquer the province of Bengal and was edging westwards. As this government of joint stock company-turned-rulers also appropriated the forms and personnel of the vanquished Mughal and post-Mughal regional governments, ${ }^{76}$ mahzar-namas remained meaningful and, it appears, useful to the legal actors of north India, the erstwhile Mughal Hindustan. In

\footnotetext{
75 Alam, Crisis of Empire, 175-203; J. S. Grewal, The Sikhs of the Punjab (Cambridge: Cambridge University Press, 1998), 82-98.

${ }^{76}$ For some key discussions of this process of appropriation, see Christopher A. Bayly, Empire and Information: Intelligence Gathering and Social Communication in India, 1780-1870 (Cambridge: Cambridge University Press, 1998); Robert Travers, Ideology and Empire in EighteenthCentury India: The British in Bengal (Cambridge: Cambridge University Press, 2007).
} 
this section, I shall briefly consider three mahzar-namas produced between the late eighteenth and mid-nineteenth centuries. Each of these documents exhibits striking continuities and developments, both in form and purpose, in this unique Indo-Islamic legal form.

The first document is from Batala, a sizeable town and the headquarters of a district since the sixteenth century, with its own qazi at least since that time. In the 1770s, the town and area were ruled by a Sikh misl (political group) associated by marriage with Ranjit Singh, who would eventually unite the warring misls into a Sikh empire in the early nineteenth century. ${ }^{77}$ The document calls itself a tazkara (lit. "mention"), and the earliest of the five variously dated seals affixed on it is that of a certain Qazi Muhammadi, dated 1187 AH (1773 CE). There is another seal of a certain Muhammad Shah (office unspecified) for $1194 \mathrm{AH} / 1780 \mathrm{CE}$, and a third of an officer who was neither Muslim nor Sikh, called Sewak Ram, dated 1840 Samvat $(1785 \mathrm{CE}){ }^{78}$ There are two other seals with Sikh invocations (akal sahai) from the 1870s.

This document forms part of yet another collection of "family papers," this time pertaining to the well-known Bhandaris, a family of Khatris. Khatris were a range of caste groups that had prospered in the eighteenth century as scribes and administrators (and due to consequent capital and connections, as merchants) due to Mughal efforts at socially specific recruitment to combat rebellion in the region. ${ }^{79}$ Successful under several regimes, including eventually the British, the Bhandari family built up significant urban and rural estates in the 1690s. An early family member, Sujan Rai Bhandari, wrote a very important history of the region. ${ }^{80}$ According to this tazkara document, a certain Nanak Baksh, son of Karan Chand, Khatri, alias Nayyar, resident of Bulharwal, a suburb of the town (qasba) of Batala, narrated that a Rai Singh Sundar had pawned a large house (haveli) with him for 2,950 rupees. The transaction proved to be a fraught one because Sundar disputed it, but Nayyar managed to prove it in the court of Khalsa Jiu (the Sikh state, represented by the local Sikh Governor) by producing the pawn document (rahn-nama), which bore the attestations of some of the local residents. Unluckily for Nayyar, that crucial rahn-nama document had been lost, and he now feared that the former owners might attempt to re-open their claims. To preempt that, Nayyar wrote, as one might expect, "Nanak Baksh ... asks (sawal mi kunad) and wants a declaration of his situation (wa ishtehar-i hal-i khud mi khawad)," which he then proceeded to describe. In the end, he requested "whoever is aware of the true position and the veracity of this [his] statement, that they may add their testimony

77 J. S. Grewal, In the By-Lanes of History: Some Persian Documents from a Punjab Town (Simla: Indian Institute of Advanced Study, 1975), 4-5.

${ }_{78}$ Vikram Samvat is one of the two main pre-Islamic Indian eras, the other being Saka.

79 Alam, Crisis of Empire, 169-75.

${ }^{80}$ Sujan Rai Bhandari, Khulasatu-t-tawarikh, M. Zafar Hasan, ed. (Delhi: J \& Sons Press, 1918). 
(shahadat) to this tazkara, for God's sake (hisb Allah) so that they may be "rewarded by God and thanked by men ('and Allah majur wa 'and al-nas mashkur)." The document acquired around eighty-five attestations, of which eighteen were in Persian and the rest in Landa and Gurmukhi scripts. Only one of the fifteen signatories in Persian was a Muslim man, named Shaikh Rashid. As we have seen, the document was topped by the seal of Qazi Muhammadi, who used the standard epithet for himself — khadim-i shari 'a — but clearly, other official seals were considered necessary over the years. ${ }^{81}$

This document was certainly different in some important ways from those we have been looking at. For example, it called itself a tazkara, and it did not begin with the standard Quranic verse exhorting the rendering of testimony, though that omission was possible even in Mughal times, as Purshottam Das of Malwa had similarly left this out. On the other hand, it began and ended with the standard appeals for testimony and conformed almost exactly to the model offered by the nearcontemporary formulary of Shakir Khan. The first-person voice of the narrative, the nature and purpose of the claims (to create evidence when crucial documents were lost or ineffective), and the style of collective endorsements by the associates of the protagonist - all this was in line with Mughal mahzar-namas, as was the role of the qazi as only one among several validating authorities.

Given the story presented in this paper, it may be no surprise that the Mughal form of the mahzar-nama found many uses within a post-Mughal north Indian political context. What ought to be equally unsurprising, given the well-known layering of the Mughal and British empires, is comparable continuity several years into the advent of British colonialism in northern India. The last two mahzar-namas in this paper display how the distinctively hybrid features of the mahzar-nama - Islamicate and Persianate, located between law and politics, state and community - fully emerged during this period during which people sought cultural resources for expressing their sense of right and wrong in a bewilderingly new world.

The first of these mahzar-namas was produced around 1784, around the same time as the first tazkara from the Punjab. It was produced in connection with a legal event known to most historians of the British Empire - the impeachment trial of Warren Hastings. Peter Marshall's classic book about this trial mentioned a letter of support that was produced in Sanskrit by the pandits of Banaras, on the instigation of Warren Hastings' protégé in that recently-conquered city, a Shi'a Muslim bureaucrat-turned-judge named Ali Ibrahim Khan. ${ }^{82}$ Ali Ibrahim Khan did indeed produce that letter of support for his old patron, but the

81 J. S. Grewal, In the By-Lanes of History: Some Persian Documents from a Punjab Town (Simla: Indian Institute of Advanced Study, 1975), 299-302.

${ }^{82}$ Peter Marshall, The Impeachment of Warren Hastings (London: Oxford University Press, 1965). For a fuller discussion of Ali Ibrahim Khan's life and legal ideas, see Chatterjee, "Hindu City." 
impending trial no doubt also made him anxious about the security of his own position, and he took the opportunity to collect endorsements for himself. Thus was produced an extraordinary mahzar-nama, perhaps the largest in India. This 27 foot-long document is an exuberant one in which Ali Ibrahim Khan described his main achievements as magistrate of Benares, first in Persian, and then a highly Persianized but also highly localized Hindi written in Nagri, complete with the Hindu invocation "Sri Ganeshai namah." He ended by appealing to all "commoners and gentle-folk (wazi" wa sharif)" to seal and sign the document, of their own free will, "based on/for the sake of faith and righteousness (az ru-yi iman wa dharam)"- -using the explicitly Hindu word dharam. In doing so, the professional and social connections of this extremely well-connected man wrote in Persian, Hindi, Sanskrit, Tamil, and Bengali. Some used terse, legal language ("the account is true"), others a gently pious language of goodwill ("God keep Mr. Hastings and the Company well that he has appointed such a judge for Benares"), and still others a mythic language of just kingship that saw in Ali Ibrahim Khan the qualities of the kings of the Brahminical Golden Age (satyayug). ${ }^{83}$

Ali Ibrahim Khan's mahzar-nama was the product of a period of political and cultural transition in response to political and legal events that were both local and global. It was the response of a man trained in the Mughal administrative tradition, but deeply sensitive to the altered political situation, who was attempting to negotiate a new legal landscape with familiar resources, especially this one that worked best for those with wide and supportive social networks. How well Ali Ibrahim Khan's carefully garnered evidence would have fared in an imperial/colonial tribunal we do not know, since this document was never produced in a court. But there is no reason to be optimistic, because we do know of Burke's assertion that the "florid testimonials" from Indians demonstrated Hastings' tyranny rather than his popularity. ${ }^{84}$

The second colonial-era mahzar-nama was produced in 1857 , under conditions that can be called "suspended colonialism." It was scribed in the Mughal capital of Delhi, where for a period of just less than five months British control was overthrown by rebelling Indian soldiers, who forced the aged Mughal emperor to take on the mantle of kingship. ${ }^{85}$ Surviving records from these months show that an active culture of litigation formed around a

\footnotetext{
83 "Certificate of the Inhabitants of Benares in Support of Ali Ibrahim Khan'," Add. 29,217(a), British Library, London.

84 Jennifer Pitts, A Turn to Empire: The Rise of Imperial Liberalism in Britain and France (Princeton: Princeton University Press, 2005), 67.

${ }^{85}$ There is a vast historiography of the 1857 mutiny of soldiers and coincident civil rebellion in northern and central India. The book that records the events of Delhi most closely is William Dalrymple, The Last Mughal: The Fall of a Dynasty, Delhi, 1857 (London: Bloomsbury, 2006).
} 
hybrid tribunal that was set up in the Red Fort. ${ }^{86}$ Prostitutes complained of unpaid dues, and brothers-in-law of fugitive sisters-in-law, and soldiers bickered over the ownership of swords. Testimony was recorded, agreements signed, and judgments delivered. ${ }^{87}$ Meanwhile, the regime tried keeping various elements together, among other things by declaring a prohibition on cow-slaughter, no doubt in an effort to mobilize the Hindu soldiers. This left the butchers of the city in the lurch, and a certain Hafiz 'Abd al-Rahman was arrested together with them on suspicion of cow-killing. The fellow managed to put together a mahzar-nama from inside prison in which he claimed that he was not of the community of butchers, but merely a man who had taken up making kababs because livelihoods were hard to come by. ${ }^{88}$

While this mahzar-nama's format is exactly the same as the other Mughal ones that I have discussed, including in its Quranic verse and opening and closing formulae, it is in Urdu, albeit a heavily Persianized Urdu with Persian grammatical forms (such as the adjective following the noun). It uses non-Persian Hindustani words where the Arabic word is still used in legal documents today (such that the author called himself "beta-yi Panna Shah" rather than "walad-i Panna Shah" or even the "bin [ibn] Panna Shah"). ${ }^{89}$ The document was also very poorly scribed, possibly indicating the difficulty of procuring a skilled professional scribe under the circumstances and, if that is true, it shows the social percolation of knowledge and wide acceptance of this documentary form for legal purposes. In any case, the understanding that such a document, duly completed with endorsements, formed acceptable legal evidence was shared by the appellant and the court he appealed to. We know this because, unusually, we also have the petition, which the mahzar-nama accompanied, transcribed with the order that 'Abd al-Rahman should be released. $^{90}$

\section{CONCLUSION}

From Purshottam Das to 'Abd al-Rahman, mahzar-namas offered a legally effective instrument, which a range of protagonists in Mughal India used to represent their claims of entitlements and injuries. They did so with their eyes on

\footnotetext{
86 On this tribunal, see Iqbal Husain, "The Rebel Administration of Delhi," in Shireen Moosvi, ed., Facets of the Great Revolt, 1857 (Delhi: Tulika 2008), 23-38.

87 Translations of many of these records are in Mahmood Farooqui, Besieged: Voices from Delhi (Delhi: Penguin, 2010).

${ }^{88}$ Mahzar-nama of Hafiz Abdur Rahman signed by several citizens of Delhi, Mutiny Papers, National Archives of India, Coll. 103-31.

89 This displays the diglossia, or unstable movement along a spectrum of registers, that characterized the relationship between Urdu and Persian well into the nineteenth century. Javed Majeed, " "The Jargon of Indostan': An Exploration of Jargon in Urdu and East India Company English," in Peter Burke, ed., Languages and Jargons: Contributions to a Social History of Language (Cambridge: Polity Press, 1995), 182-205.

90 Farooqui, Besieged, 161-62.
} 
not only law and legal processes, but also power, politics, and social ties. Homonymous with a classical Islamic documentary form, the mahzar, which was approved of by leading Islamic jurists of India and elsewhere, Indian mahzarnamas were distinctly hybridized in both form and function and along a number of trajectories. While the dominant southwestern Indian form developed the declarative and collective features of mahzars, for which they were favored by kings and saints, this development took place within a complex and evolving context in which Islamic states gave way to ideologically Brahmanical regimes overlaying powerful rural community structures. Ironically, the closest real-life application of the jurists' model of mahzar was in the multisectarian, community-centered courts of the Maratha Empire, within which the Islamic qazi was only one of many sources of authority.

In Mughal north India the mahzars took on a different form, designated mahzar-nama in line with allied forms of legal documentation found across the Persianate world, principally Iran and Central Asia. Like other forms of collective testimony, such as ishtishhad-nama documents from Qajar Iran, Indian mahzar-namas included the visually striking feature of multiple endorsements by associates and supporters of the person articulating his or her claims. This revealed the protagonists to be proactive legal actors capable of mobilizing their social and professional networks and co-opting the qazi's authority so that his seal could notarize truths that could then be carried beyond the jurisdiction of his court. Unlike the mahzars from the Maratha country, such endorsement appears to have been drawn from situationally mobilized social networks rather than stable corporate groups. This should encourage us to reflect upon the surprising levels of individuation present in the legal and social worlds of Mughal India, but also the capacity for purposive collective action. Such active mobilization of local social forces inevitably implied a much more vibrant engagement between orality and literacy in the Indian mahzar-namas than is visible in any comparable Persianate legal documentary form. The complexity of the Indian interface between orality and literacy was magnified by multilingual, multi-denominational, and assertive legal actors, who brought to the mahzar-namas not only their own languages and scripts, but also different symbols of value derived from multiple religious and status positions.

It appears likely that the form of the Mughal mahzar-nama came to be standardized through interactions of Islamic legal forms and concepts, Indian administrative and adjudicative practice, and the attentions of Persian-writing scribes and litterateurs. Thus hybridized, the mahzar-nama acquired a distinctively Indo-Islamic form. This included strikingly direct appeals to Quranic authority when seeking and recording testimony, appeals that, though not so intended, presaged the "modernist" religious revolution whereby eventually jurists and law were bypassed with reference to direct access to scriptures and personal piety.

Whatever our protagonists thought of the judges, they did tell us what they thought of themselves and their rights and obligations. It appears from these 
documents that in identifying their rights Indians valued the past, not in a collective homogenous sense, but through an intensely personal trajectory of time. The narrative form of the mahzar-nama depicted a violated or threatened past that they sought to restore. Yet antiquity alone did not establish entitlement, and mahzar-namas inevitably asserted and expanded upon the spiritual, professional, and personal achievements of the author. Thus the death of a learned man was an injury because the world lost his learning, piety, and precious library. Lost documents had to be recreated because they recorded offices gained or money earned by the protagonists themselves or their illustrious immediate ancestors. A good judge and administrator could ask all those who had experienced his excellent professional conduct to testify to his qualities in good conscience.

Derived from Islamic jurisprudence, kin to comparable documents in Perso-Islamicate contexts, yet distinctively regionalized in the Indian subcontinent, mahzar-namas offer a fragmentary but kaleidoscopic insight into the meanings of law in the Indian subcontinent, from under Mughal rule to colonialism. They allow us to take law beyond its undeserved image as the "state's emissary" and instead decode some everyday notions of rights and wrongs in early modern South Asia through the articulate assertions of ordinary litigants. They let us disregard, for a while, the claim of imperial regimes to be the ultimate and exclusive referee of legal truth, and they remind us that law is, after all, about the aspiration for justice.

\begin{abstract}
This paper looks at a Persian-language documentary form called the mahzar-nama that was widely used in India between the seventeenth and nineteenth centuries to narrate, represent, and record antecedents, entitlements, and injuries with a view to securing legal rights and redressing legal wrongs. Mahzars were a known documentary form in Islamic law and used by qazis (Islamic judges) in many other parts of the world, but in India they took a number of distinctive forms. The specific form of Indian mahzar-namas that I focus on here was, broadly speaking, a legal document of testimony, narrated in the first person, in a form standardized by predominantly non-Muslim scribes, endorsed in writing by the author's fellow community members and/or professional or social contacts, and notarized by a qazi's seal. This specific legal form was part of a much broader genre of declarative texts that were also known as mahzars in India. I examine the legal mahzar-namas together with the other kinds of mahzars, and situate them in relation to Indo-Islamic jurisprudential texts and Persian-language formularies. What emerges is a distinctive Indo-Islamic legal culture in contact with the wider Islamic and Persianate worlds of jurisprudence and documentary culture, but responsive to the unique socio-political formations of early modern India. I also reflect on the meanings of law, including Islamic law, for South Asians and trace the evolution of that understanding across the historical transition to colonialism.
\end{abstract}

